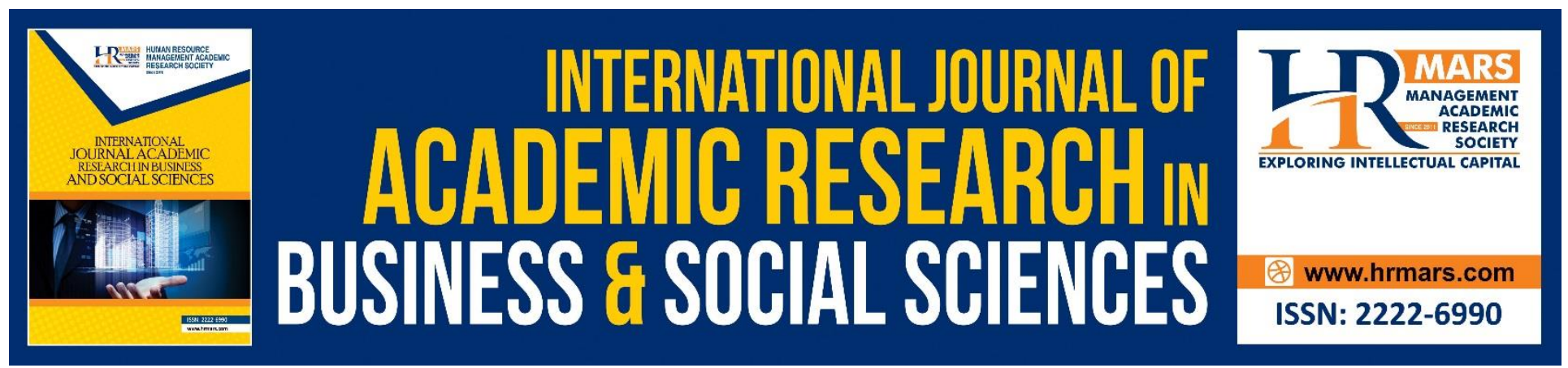

\title{
Concept and Execution of Talaqqiand Musyafahah Method in Learning Al-Quran
}

Nor Hafizi bin Yusof, Mohd A'tarahim bin Mohd Razali, Najmiah binti Omar, Mohamed Fathy Mohamed Abdelgelil, Mohd Shafiee bin Hamzah

To Link this Article: http://dx.doi.org/10.6007/IJARBSS/v8-i11/4930～DOI: 10.6007/IJARBSS/v8-i11/4930

Received: 19 Oct 2018, Revised: 12 Nov 2018, Accepted: 22 Nov 2018

Published Online: 06 Dec 2018

In-Text Citation: (Yusof, Razali, Omar, Abdelgelil, \& Hamzah, 2018)

To Cite this Article: Yusof, N. H. bin, Razali, M. A. bin M., Omar, N. binti, Abdelgelil, M. F. M., \& Hamzah, M. S. bin. (2018). Concept and Execution of Talaqqi and Musyafahah Method in Learning Al-Quran. International Journal of Academic Research in Business and Social Sciences, 8(11), 559-565.

Copyright: (C) 2018 The Author(s)

Published by Human Resource Management Academic Research Society (www.hrmars.com)

This article is published under the Creative Commons Attribution (CC BY 4.0) license. Anyone may reproduce, distribute, translate and create derivative works of this article (for both commercial and non-commercial purposes), subject to full attribution to the original publication and authors. The full terms of this license may be seen

at: http://creativecommons.org/licences/by/4.0/legalcode

Vol. 8, No. 11, 2018, Pg. 559 - 565

http://hrmars.com/index.php/pages/detail/IJARBSS

JOURNAL HOMEPAGE

Full Terms \& Conditions of access and use can be found at http://hrmars.com/index.php/pages/detail/publication-ethics 


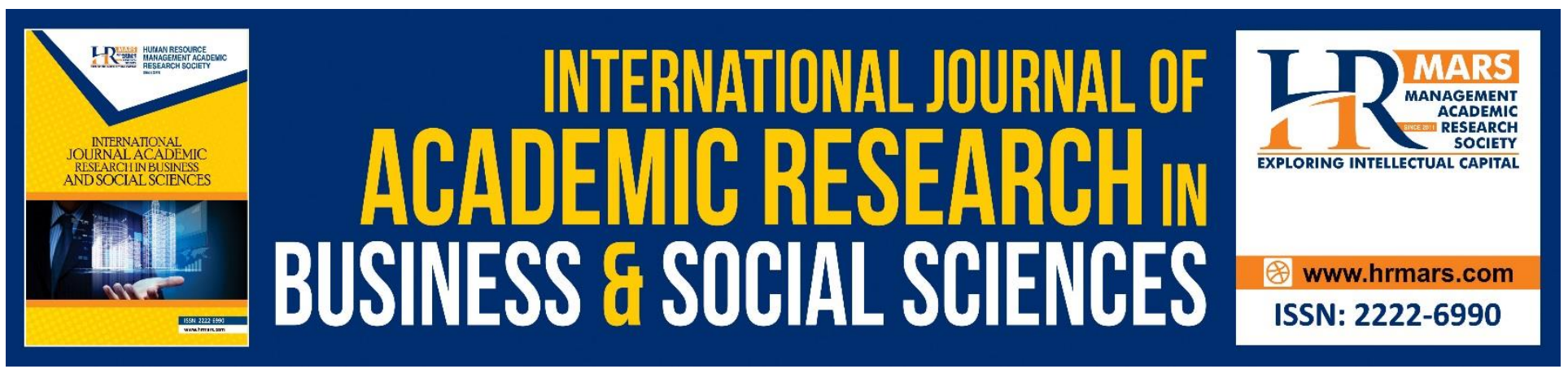

\title{
Concept and Execution of Talaqqiand Musyafahah Method in Learning Al-Quran
}

\author{
Nor Hafizi bin Yusof \\ Email: nhafizi@unisza.edu.my \\ Mohd A'tarahim bin Mohd Razali \\ Email: atarahim@unisza.edu.my \\ Najmiah binti Omar \\ Email: najmiah@unisza.edu.my \\ Mohamed Fathy Mohamed Abdelgelil \\ Email: mfathy@unisza.edu.my

\section{Mohd Shafiee bin Hamzah} \\ Email: mshafiee@unisza.edu.my
}

\begin{abstract}
Talaqqi musyafahah is a method of learning the Quran face to face where the delivery and teaching method is directly from a teacher to a student. This Quran learning method was inherited by Rasulullah s.a.w. from Gabriel a.s and further transferred to the companions. The companions continued this pedagogy until it is widely accepted as one of the Quran learning systems today. The development of the education system has featured a diverse Quran learning system, including distance learning and through the internet. These new methods have raised issues whether they fulfil the talaqqi musyafahah system taught by Rasulullah s.a.w. This study introduces the concept of talaqqi and musyafahah, the importance of talaqqi musyafahah and its implementation in learning the Quran. This qualitative study chose the descriptive method to collect and analyse the opinions of the Muslim scholars via authoritative and related books, journals, and web sites. As a conclusion, any Quran learning method must conform to the talaqqi and musyafahah methods taught by Rasulullah s.a.w.
\end{abstract}

Keywords: Talaqqi, Musyafahah 


\section{INTRODUCTION}

The term talaqqi is derived from an Arabic word (لقي) which means to meet (al-Marbawi, 1990) and musyafahah is derived from (شفة) which means directly receiving verbally (al-Marbawi, 1990). The combination of these two words means to learn the Quran individually and face to face from a qualified teacher. In other words, it is currently defined as face-to-face and one-to-one learning with a qualified teacher. Allah says in the Quran that the actual method of learning the Quran by Rasulullah $\mathrm{SAW}$ is by talaqqi with Gabriel a.s.:

"And indeed, [O Muhammad], you receive the Qur'an from one Wise and Knowing."

This method was then implemented by Rasulullah among the companions. The companions continued this pedagogy until it is accepted as one learning system by the qurra and past schools for learning the Quran. It was quoted by al-Imam Ibn al-Jazari from the words of Zaid bin Thabit in his book Munjid al-Muqriin (al-Jazari: 20):

"The Quran recitation is the sunnah that is received via talaqqi by someone in the later generation from someone in the earlier generation."

Therefore, the Quran learning method does not accept any human interpretation and analogy and this discipline continues until it becomes obligatory in learning the Quran.

\section{TALAQQI AND MUSYAFAHAH CONCEPTS Definition of Talaqqi}

The term talaqqi is derived from an Arabic word (لقي) which means to meet (Mohd Idris Abdul Rauf al-Marbawi, 1990: 225) or the meeting between student and teacher face to face. It also means learning the Qur'an directly by listening and copying verbally from a teacher who has a continuous chain (sanad) from Rasulullah SAW. According to Abd al-Salam Muqbil (2000), the word talaqqi is taken from الإلقاء which means throwing by hand or conveying verbally.

However, the term talaqqi means a learning methodology outlined by syara' in the Quran teaching where the teacher recites the Quran and the student receives through listening and understanding. It completes the process of al-talqin which means the delivery from the teacher and al-talaqqi is the reception by the student. The talaqqi process has three components (Abd al-Salam Muqbil al-Majidi, 2000):

i. المتلقي the student

ii. الملقي the theacher

iii. الملقى the knowledge or Quran

\section{Talaqqi Concept}

All the Qurra' unanimously agreed that the Quran is sunnah muttabaah (following in worship) that is inherited with sanad from Rasulullah saw. This was clear in the discipline of narration and recitation of the Quran practiced by the pious predecessors as mentioned by Umar al-Khattab (Ibn Mujahid, 1980) "The Quran recitation is a sunnah that is followed and received by the later generation from the earlier generation."

Ilmam al-Qurra' Ibn al-Jazari emphasised (n.d: 10) in his book al-Nasyr fi al-Qiraat al-Asyr: 
"The Qiraat imams did not practise with the ahruf of the Quran on the basis of language and analogy in Arabic language, but by referring to what was confirmed via hadith and authentic riwayat. Any confirmed riwayat does not depend on the analogy method of Arabic language and what is famous in Arabic language because the Quran recitation is a sunnah that shall be followed, must be accepted and practised upon it."

The nass explains the concepts of talaqqi al-Quran practiced by the pious predecessors:

i. Learning the Quran is simply the sunnah which is followed through the concept of talaqqi verbally.

ii. It must be based on the concept of talaqqi from a teacher who has who has a continuous chain (sanad) from Rasulullah s.a.w.

iii. It is compulsory to receive the Quran recitation method with a continuous chain (sanad) from Rasulullah s.a.w.

iv. It is forbidden to use the method of Arabic language or analogy method in the Quran recitation when the riwayat is confirmed mutawatir.

\section{Types of Talaqqi}

Dr Ahmad bin Faris al-Salum (2016) classified the types of talaqqi among the Qurra' into five types:

i. Al-Talqin (التلقين)

The teacher reads the Quran to the students using the authentic recitation as practised in the basic level of education of children. This is the best method because it is a way of learning that was practised by the predecessors among the companions and tabi'in as stated by Ibn Abbas (Ibn Kathir, $1416 \mathrm{H}$ ):

ii. Al-'Ard (العرض)

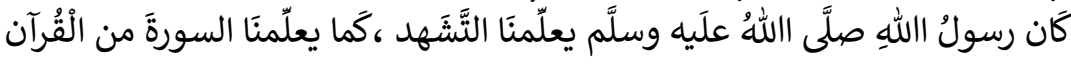

Al-'Ard means a student recites the Quran in front of a teacher as practised by most of the Qurra'. This method is usually done after the student memorises the verses that are received via talaqqi from the teacher. This method was practised by the Salaf and Khalaf.

iii. Al-Sima'(السماع)

This method is intended for the teacher to recite the Quran as an example. Most of the scholars claimed that this method is inadequate even if it was practised by some of the scholars in the early era or mutaqaddimin. Some of the companions also practised this method in learning the Quran. It was not a big issue because they were very fluent and were able to recite the Quran precisely following the recitation of the teacher, although not in front of the teacher. Among all the Qiraat Imams, Imam Kisaie was reported to practise this method. Ibnu Mujahid mentioned that the public learned from Imam Kisaei by listening to his recitation and marked in their mushafs (Ahmad Mahmud Abd al-Sami', 2002).

iv. Riwayat al-Huruf (رواية الحروف)

This is a rare method and most of the books on the knowledge of the Quran do not mention this method as one of the Quran talaqqi methods among the qurra'. Via this method, the students only learn the Quran recitation from a teacher through narration only without 
INTERNATIONAL JOURNAL OF ACADEMIC RESEARCH IN BUSINESS AND SOCIAL SCIENCES Vol. 8, No. 11, Nov, 2018, E-ISSN: 2222-6990 @ 2018 HRMARS

reciting in front of the teacher. This method is common during a talaqqi of a book that narrates the Quran recitation riwaya or the recitation method of certain Imam.

v. إإزازة المجردة)

This method involves a teacher recognising the recitation of a student. For example, the teacher says: "I confer this ijazah to you with this recitation of the Quran". However, this method requires two conditions:

a. The teacher recites the Quran to the student and the teacher recognises the student to be intelligent and able to understand and recite well, therefore the teacher will confer the ijazah to the student.

b. The teacher recognises the student to be intelligent and can recite the Quran well, thus the teacher tests the student's recitation and confers ijazah.

\section{DEFINITION AND CONCEPT OF MUSYAFAHAH}

Musyafahah literally means receiving verbally from the movement of the lips. However, this term refers to the situation where the student receives the knowledge verbally by focusing on the movement of the teacher's lips and repeat the recitation. Talaqqi Musyafahah refers to the face-toface meeting between a teacher and a student in a gathering at any time where the student focuses on the movement of the teacher's lips and repeats the recitation or the teacher listens to the student's recitation and correct any mistakes (Ja'far bin Nik Ismail (Ismail, 2004). In musyafahah, two common methods are used in the Quran teaching and learning process. First, the teacher recites the Quran and the student only listens. Second, the student recites the Quran in front of the teacher while the teacher listens and corrects any mistakes.

\section{THE IMPORTANCE OF TALAQQI MUSYAFAHAH}

Talaqqi musyafahah is important in learning the Quran because there are a few words that have

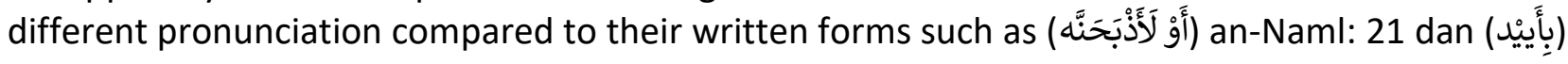
al-Zaariyat: 27. The same goes to the specific Hafs recitation techniques for certain words such as

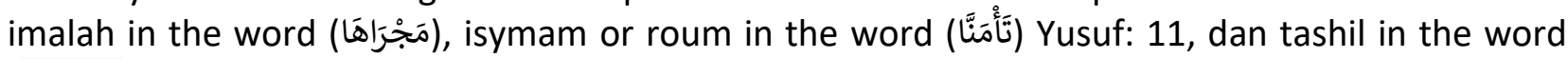
(s) Fussilat: 44 that cannot be learned and recited only br referring to their writings in the mushaf or any tajwid books, but to learn via talaqqi musyafahah with a qualified teacher.

This method is also important because it was taught by Rasulullah s.a.w. and practising this method ensures the continuity of sanad (Amin, 2012), where the stipulations in the Quran recitation are authentic sanad, fulfils Uthmani rasm, and meets any one of the Arabic lahjah as stated by Imam Ibnu Jazari (al-Jazari 1994):

"Any text that complies with the rules of Arabic language and meets the Uthmani rasm, partially or completely, as well as the authentic sanad is considered as the Quran. The absence of any of these three stipulations would deem it as shaz although the recitation is from any of the seven Qiraat." 


\section{IMPLEMENTATION OF TALAQQI IN LEARNING THE QURAN}

The learning of the Quran by talaqqi musyafahah is inherited from Rasulullah s.a.w. It was narrated that Rasulullah s.a.w. recited the Quran in front of Gabriel a.s once a year in Ramadan and in the year in which he died, he recited the Quran twice.

In talaqqi musyafahah, the student must learn the Quran directly from the teacher because all the teachers who teach the Quran have the sanad continued to Rasulullah s.a.w. It is very important to learn the Quran with a teacher via talaqqi musyafahah as taught by Rasulullah s.a.w. Allah says in the Quran:

"Move not your tongue with it, [O Muhammad], to hasten with recitation of the Qur'an. Indeed, upon Us is its collection [in your heart] and [to make possible] its recitation. So when We have recited it [through Gabriel], then follow its recitation."

(al-Qiyamah:16-18)

\section{Fundamentals of Talaqqi Implementation}

The methods and implentation of al-Talaqqi dan al-Talqin (Abd al-Salam Muqbil al-Majidi, 2000:137) are as follows:

i. The teacher recites to the student as what Gabriel did towards Rasulullah s.a.w.

ii. The student listens and understands the teacher's recitation

iii. The student recites the verses precisely

iv. The student's recitation is by moving the lips and reciting in jahr (loud)

\section{CONCLUSION}

Talaqqi and musyafahah is a discipline of learning the Quran inherited by Rasulullah s.a.w from Gabriel a.s and practised by the companions. This method was also practised and recognised by the pious predecessors as the best way of learning the Quran. This method is important for ensuring the continuous chain (sanad) from Rasulullah s.a.w. and authenticating the recitation of the Quran. Through time and technology, the talaqqi and musyafahah remains recognised as the fundamental in learning the Quran along with the recent methods such as al-Baghdadi, al-Tikrar, religious gathering (halaqah), and through the internet.

\section{Acknowledgement}

We express our deepest gratitude to the Centre for Research Management, Innovation \& Commercialization (RMIC) as well as Faculty of Islamic Contemporary Studies, Universiti Sultan Zainal Abidin, Terengganu, Malaysia for supporting the publication of this article

\section{References}

Al-Majidi (2000). Talaqqi al-Nabiy Alfaz al-Quran al-Karim. Beirut: Muassasah al-Risalah.

Al-Sami' (2002), Qiraat al-Kisaie min al-Qiraat al-Asyr al-Mutawatirah. Beirut: dar al-kutub al-Ilmiyyah Al-Jazari (1994). Thayyibah An-Nasyr

Al-Salum (2016). Manhaj al-Mustasyriqin fi Ithbat al-Nas al-Qurani Ard wa Naqd. Kertas kerja dalam Muktamar al-Ishtishraq Ma lahu wa Ma Alaih. Jamiah al-Qasim pada: 14-16 Disember 2016

Ismail (2004). Buku Qawaid Tarannum: Cara Berlagu. Kuala Lumpur: Darul Fikir. Al-Jazari. (n.d.) al-Nasyr fi al-Qiraat al-Asyr. Beirut: Dar al-kutub al-Ilmiyyah 
INTERNATIONAL JOURNAL OF ACADEMIC RESEARCH IN BUSINESS AND SOCIAL SCIENCES Vol. 8, No. 11, Nov, 2018, E-ISSN: 2222-6990 @ 2018 HRMARS

IbnKathir (1416H) Fadhail al-Quran. Kaherah: Maktabah Ibn Taimiyyah IbnMujahid (1980). Abi Bakr bin Ahmad, t.th. al-Sab'ah fi al-Qiraat. Kaherah: Dar al-Maarif Abbas, I. (1985). Memahami Tajwid dan Tartil al-Quran. Kuala Lumpur: Dewan Bahasa dan Pustaka Ridhuan, J. (2000). Kaedah pengajaran dan pembelajaran al-Quran. Kuala Lumpur: Pustaka Salam Sdn. Bhd

Kementerian Pendidikan Malaysia. 2003. Buku panduan pengajaran dan pembelajaran pendidikan Islam. Jabatan Pendidikan Islam dan Moral Qattan, M.K. (n.d.) Mabahis fi Ulum al-Quran. Maktabah Wahbah: Kaherah. Ahmad, M.Y. (2000). Sejarah dan Kaedah Pendidikan al-Quran. Kuala Lumpur: Penerbitan Universiti Malaya

Amin, M.D. (2012). al-Nur Wa al-Burhan fi Ahkam Tilawah al-Quran. Kahera : Maktabah Aulad alSheikh Li al-Turath 